\title{
THE LOCAL STRATEGY FOR THE SUPPORT OF FAMILY LITERACY
}

\author{
Alica Petrasová
}

\begin{abstract}
The family literacy concept makes explicit what has been implicitly understood, and recognizes the family as an institution for education and learning and the role of parents as their children's first teachers. The starting point for the development of human resources within a culture is the family. Families provide an intergenerational transfer of language, thought, and values to the minds of their new-born infants and throughout the formative years of their children's lives. Families provide initial guidance in learning to use the cultural tools that will be valued and rewarded within the culture. Families interpret the culture for their children, and they mediate the understanding, use, and value placed on the cultural tools for learning and education, of which the capstone tools are language and literacy. The author presents the European partnership project Literacy Cubed - Focus on Roma Families. The programme was piloted in three countries: Montenegro, Romania and Slovakia from December 2013 to November 2015. Project LIT³ supports the reading and health literacy skills development of three generations: primary school children (aged 6-11), their parents/carers and their grandparents. The goal of Project LIT³ was to raise the attainment level of Roma children in general education. Non-governmental organization Orava Association for Democratic learning is the main coordinator and implementer of the project in Slovakia. We present the experiences of the project team with requesting and engaging of stakeholders of the Literacy Cubed - Focus on Roma families (LIT3) project in the city of Dolný Kubín (Slovakia) in the paper.
\end{abstract}

\section{Keywords}

Roma family, family literacy - reading and health, children from socially disadvantaged backgrounds

\section{Introduction}

It is mentioned that the Roma population, in contrast to the European, is young; in the document of EU framework for national strategies for the Roma inclusion, that is part of the Europe 2020 strategy, nearly 36 \% of Roman are in fact younger than fifteen 
years compared to nearly $16 \%$ of EU citizens. Likewise, the average age of the Roma is twenty-five years, while it is forty years in the EU. The Europe is losing labor when not using the Roma potential. A key aspect in this respect, therefore, will be particularly to emphasize their higher level of education in order to qualify for better jobs. The member states of the European Union still have the primary responsibility for the integration of the Roma population in hands at present because the main challenges that are faced by the Roma fall within their jurisdiction. In particular, it is about the area of access to the quality of education, the labor market, housing, basic services, and health care. The local and regional authorities are responsible for those policies in most cases within states. It means that the authorities at the national and regional levels are responsible for the inclusion of Roma.

The Slovak Republic is bound by the Convention on the Rights of the Child ${ }^{1}$, which declares that education must lead to the development of the child's personality, talents and mental faculties to the most possible extent. It must prepare the child for an active life in adulthood in a free society, and reinforce respect for the child's parents, its own cultural identity, language, values and cultural background and values of others. Education of the Roma children and pupils, based on their social situation, the need to improve their educational level and participation in social life with success in the labor market require the complex solution of the problem from the perspective of children and pupils from the socially disadvantaged environment in the school educational system. Slovakia ranks among the countries with the greatest differences in the students' results by the achieved level of the parental education. The fact that Slovakia belongs to the countries with the greatest influence of student's socio-economic background of pupils on their performance is also an important finding. (PISA, 2003, 2006, 2012, 2015).

The school education of Romani pupils is specific and it requires taking into consideration preconditions for education with which a pupil begins his/her educational trajectory. School, or teachers who are working with these pupils should know socio-educative characteristics of Romani pupils from the environment of social exclusion, because it is their character that determines the course itself, the agents of education and subsequently the objective of the educational path. To emphasize the specificity of school education, including the importance of pre-school education, school maturity and preparedness, possible educational or pedagogical difficulties, educational needs, methods and models of management of the educational process, but also the necessity of active cooperation with family, or alternatively cooperation with non-profit sector is hopefully not necessary here (Kaleja, 2015; Kaleja, 2014; Kaleja, 2013; Kaleja, 2011; Kolaříková, 2015).

1 The General Assembly of the United Nations adopted the Convention on the Rights of the Child on 20 November 1989. 


\section{Literacy, Family Literacy and Family Literacy Programs}

Literacy was once defined as the ability to read and write. It was considered as a set of neutral and objective skills independent of social context or ideology. Ethnographic research has shed light on a wide range of culturally specific literacy practices among different communities. Literacy extends beyond the acquisition of reading and writing skills. It entails the ability to use these skills in a socially appropriate context. The very notion of literacy is also evolving to include the skills required to function in a technological society. For example, literacy has come to be used to refer to a wider domain of activities, from media literacy and computer literacy to citizenship life. With this in mind, family literacy programs must address an expanded definition of literacy in all its complexity. The term family literacy is used in several ways: (1) to describe the study of literacy in the family, (2) to describe a set of interventions related to literacy development of young children, and (3) to refer to a set of programs designed to enhance the literacy skills of more than one family member. This article explores family literacy in the second and third sense. It focuses on intergenerational family literacy programs that work with the family rather than on the child or the adult separately. Such programs assume that the greatest impact on literacy development is achieved by combining the effects of early childhood interventions; early parenting strategies, increased adult literacy, and enhanced parental support for children's school related functioning. Family literacy draws on multiple academic traditions, among them adult literacy, child literacy education - in particular the field of emergent literacy and special education, early childhood development, cognitive psychology, and parent education.

The partnerships between schools, families and communities contribute to improved student achievement and higher performance for schools. Effectively engaging families and communities around student literacy can lead to increased reading and writing skills for students. This is true for families from different backgrounds and income levels. Several research studies have supported a notion that many teachers have had for a long time: that children who have been read to at home and community come to school with important early literacy skills. They are prepared to learn to read and write. Children who have not had many experiences listening to books read aloud or talking about books typically start school with poor early literacy skills. These children often fall behind early in reading and writing and stay behind.

The concept of family literacy is firmly rooted in a substantial research base from several disciplines, including adult literacy, emergent literacy, child development, and systems analysis. Family literacy is a term used to describe parents and children - or more broadly adults and children - learning together. Also known as intergenerational literacy, and in some cases, community literacy, the rationale underlying such work is that parents (and adults in communities) are children's first teachers; that much learning occurs beyond traditional school settings, and that learning is a lifelong process.

Family literacy can describe the way parents, family and community members use literacy at home and in their communities. Literacy activity occurs naturally during the routines of 
daily living and helps adults and children get things done. The ethnic, racial, and cultural heritages of families are reflected in the literacy activities in which they engage. Family literacy can apply to all families and all literacy activities that take place within the family, not just school-like activities. Although family literacy traditionally takes place within the family, family literacy activities and programs can be initiated by organizations outside of families.

Family Literacy programs are driven by comprehensive, holistic approaches to education in which parents and children learn and grow together. Family Literacy programs address the literacy strengths and needs of the family/community while promoting adults' involvement in children's education, recognizing adults as a powerful influence on children's academic success. Family literacy programs also recognize the reciprocal nature of parent-child relationships. Programs provide both parent-initiated and childinitiated activities to support development of those relationships and to increase the motivation to learn for both parent and child.

Designing and delivering literacy programs that benefit both parents (or other family members) and children make sense. But do family literacy programs really work? And if so, who benefits? School administrators, community leaders, and funding agents want to know the answers to these questions before deciding to support family literacy programs. In brief, the results show that family literacy programs do work and that at least four groups benefit: children, parents, families as units, and the larger society (Padak \& Rasinski, 2013; Zezulková, 2015).

\section{Children benefit from family literacy programs}

- Children's achievement in school improves.

- Children attend school more regularly and are more likely to complete their educations.

- Children's oral language development accelerates. Reading aloud to children is the single most effective parent practice for enhancing language and literacy development.

- Children become more ready to attend school.

- Children's overall reading achievement improves.

- Children's reading vocabulary improves.

- Children's phonemic awareness and decoding ability improve. They become more able to recognize unknown words in print.

- Children's comprehension improves. These separate factors: vocabulary, decoding, and comprehension - combine to support overall achievement in reading.

- Children's writing improves.

- Children's math and science achievements improve. Gains in these 3 areas writing, math, and science - are particularly impressive because so few family literacy programs address these subjects. 
- Children's social skills, self-esteem, and attitudes toward school improve. All these have the potential to support children throughout their lives.

- Children are healthier. Aside from its general importance, good health is related to higher achievement at school.

- Children's understanding of print (forms and functions) grows.

- Children's motivation to read increases.

\section{Parents benefit from family literacy programs}

- Parents persist in family literacy programs longer than in other types of adult literacy programs. Those who persist have more opportunity to learn.

- Parents' attitudes to education improve; the value they perceive in education increases.

- Parents' reading achievement increases.

- Parents' writing ability improves.

- Parents' math and science knowledge increases. This is especially true when family literacy programs include focus on these areas.

- Parents' knowledge about parenting options and child development increases. For example, parents in one project became more confident about their abilities to foster their children's positive development.

- Parents' social awareness and self-advocacy increase.

- Parents enhance their employment status or job satisfaction.

\section{Families benefit from family literacy programs}

- Families learn to value education. This finding has emerged from studies of children, parents, and families.

- Families become more involved in schools. Family involvement in schools leads to better achievement for children.

- Families become emotionally closer, which creates a more supportive home environment.

- Families read more and engage in more literate behaviours at home.

- Families build foundations for lifelong learning.

\section{Society benefit from family literacy programs}

Parents persist in family literacy programs, and persistence leads to literacy achievement, which in turn can influence broader economic and social issues. In particular, family literacy programs positively affect (or have the potential to affect) several major social problems:

- Nutrition and health problems.

- Low school achievement and high school dropout rates. 
- Teen parenting.

- Joblessness and welfare dependency.

- Social alienation.

- Home and community violence.

Family literacy is a rich and rewarding program with many potential benefits. Parents improve their literacy and parenting skills. They also increase their self-sufficiency and develop closer relationships with their children. Children are better prepared to enter school, have fewer absences, and are less likely to need additional services in school. Communities have more active and better-educated citizens. Family literacy helps agencies to manage comprehensive services in a coordinated way. It prevents duplication of services and frees up resources for other projects. It is also a program that requires dedication and hard work and a basic belief in the ability of all people to learn and be successful citizens in their own unique ways.

Family literacy programs do work, and their benefits are widespread and significant. The existing body of research points to the enormous potential of high quality family literacy programs to influence the lives of parents and children positively through family support and education.

\section{About the Project Literacy Cubed - Focus on Roma Families}

Project Literacy Cubed - Focus on Roma Families (hereinafter: Project LIT ${ }^{3}$ ) aimed to develop and disseminate effective strategies to promote family literacy (the support of reading and health education) in Roma communities with the respective to increase the educational success of Roma children in school and to improve the literacy of adult Roma. The aim of the project was to influence habits and attitudes of children and to support their parents to participate in education positively.

Project LIT³ was implemented from 12 January 2013 to 30 November 2015, through partnership of three countries (Romania, Montenegro and Slovakia). The work was performed at three locations: in Cluj-Napoca city, Romania, where two Roma families, living in two different neighbourhoods, joined the project, but both are populated by an overwhelming majority of the Romani with low socio-economic status (in fact one of the "neighbourhoods" is urban landfill, from which people live by collecting recyclable materials); in the city of Dolný Kubín, Slovakia, where it was worked mostly with integrated Roma families. In Podgorica, Montenegro, the project was focused at the Roma families living in Konik refugee camp on the outskirts of the city.

The project benefits from a diverse partnership of a research institution, an international umbrella organization, and three national NGOs, as well as six associated partners (five Roma organizations and one bureau of education). Including stakeholders in two European-level partnership meetings will provide added value to this European cooperation project. The fact that stakeholders from European countries that are not involved in the project partnership will enhance the European dimension of the project, 
and increase its chances of impact at the European level. The project's perspective on policies and practical aspects related to Roma families and education, as well as family literacy in general, will be enriched by the European partnership.

The dissemination strategy has been built on the partners' dissemination plans. The strategy includes clear indicators of successful outreach by categories of direct and indirect beneficiaries. The number of website visitors, the participants in conferences, workshop, stakeholders' WG meetings, and in roundtables will be carefully planned and monitored. Qualitative indicators are defined to ensure the optimal exploitation of results. Based on a thorough needs analysis, the family literacy program will be tested to ensure the evidence base that will inform the family literacy policy we will promote, and which will be the foundation of the local strategies for family literacy. Project LIT implementation plan focuses on: research-based policy recommendations for European and local decision-makers; stakeholder engagement; family literacy programme development and family literacy programme testing.

In the project, forty-eight Roma primary schoolchildren from four schools (two in RO, one in $\mathrm{MN}$ and one in SK), and seventy-two adults (the children's parents and grandparents) will develop their literacy skills by attending forty-eight hours of literacy workshop activities. Forty-eight secondary school students will act as reading buddies for the Roma children. Three local working groups of stakeholders will develop local strategies under the guidance of the project team. 170 doctor's surgeries will receive flyers to promote health literacy in Roma communities (www.lit3-project.eu) ${ }^{2}$.

Non-governmental organization Orava Association for Democratic Education ${ }^{3}$ was the main coordinator and implementer of the project in Slovakia. We present the experiences of the project team with requesting and engaging of stakeholders of the Literacy Cubed - Focus on the Roma Families project in the city of Dolný Kubín (Slovakia) 4 in the paper.

2 The summary report presents findings from an evaluation conducted by the UCL Institute of Education (IOE) of a pilot Family Literacy Programme carried out as part of the Literacy Cubed - Focus on Roma Families project. See: http://discovery.ucl.ac.uk/1475761/.

3 Orava Association for Democratic Education (Orava ADE) is a non-governmental organization that efforts to improve the Slovak education system by promoting cooperation and communication between communities of teachers, schools, universities, libraries, non-governmental and governmental educational institutions from the 1995 year. The Orava Association elaborates the training programs and materials for teachers and parents. It organizes conferences, seminars, round tables negotiations and regular actions to promote reading (e.g. Week of Loud Reading). The Orava Association is a member of the several national and international networks and enjoys a long-term partnership with the Ministry of Education of the Slovak Republic, the National Council of the Slovak Republic and other state administration bodies, regional and local municipality and non-governmental organizations.

4 The author of the paper has been an active investigator of the project Literacy Cubed - Focus on Roma Families. 


\section{The Stakeholders' Engagement as a Part of Local Strategy for the Support of Family Literacy}

The aim of the project Literacy Cubed - Focus on Roma Families was to develop and support effective policies at the local level that affect the development of family literacy (readership and health literacy) in local communities. As the title says (The Literacy Cubed), program connected three generations (children-parents-grandparents). More than twenty children of primary school age, twelve adults (parents and grandparents). Ten children of older school age (as friends to read), eight volunteers and five trainers were involved in the family literacy program in Dolný Kubín.

When authors of the Project LIT $^{3}$ started to think how to ensure this project to be much more than a family literacy program in local community, the idea emerged to involve various key players or stakeholders. There were representatives of institutions, organizations and individuals with a legitimate interest at the local level in the Project $\mathrm{LIT}^{3}$. Among the groups of the project stakeholders were - apart from Roma families representatives of local authorities, for example town hall, local and regional education authorities, social services, health authorities; schools and universities preparing the trainers, social workers and medical staff; families, parents and parents' associations; teaching assistants, doctors surgeries, hospitals, health care professionals; libraries and librarians; social workers; education and health non-governmental organizations, charities organization, donors, voluntary organizations, volunteers and publishers.

The main task was to gather a group of experienced and influential individuals who would represent their respective institutions and would add their family literacy in their job description. It was the step into the unknown for our project team since their participation should be voluntary, free and required their engagement. We were aware that if this project is to be active at the local level, we need to use all our local contacts and knowledge of local conditions and situations. The project team has therefore from the outset made a list of potential local stakeholders, whether individuals or institutions we approached later.

Requesting of the potential key players was realized mainly through personal meetings with the heads of the various bodies or institutions. The project team members tried to be precise in this, and although they could not always find first senior executive, they insisted to take part at the preparatory personal meeting at least. They were not sure how would requested people respond because each project was specific in something. However, they believed in the project idea and the work they performed, therefore it was not difficult for them to argue, communicate the ideas and so to gain people. Therefore, they hoped that people, who are requested, know other key players and give them more contacts, or designate people from their organizations, which turned out to be true. They also invited people and institutions that have been involved in the first phases of the project - to map the local needs.

They were aware that it was important to create highly competent and committed group of local stakeholders, the particular members of the project team have arranged personal 
meetings with those who were labelled as "must" on our list. They did not want to lose the representatives of the most important institutions because of some unforeseen reasons or due to unclear communication. Moreover, they realized that the space where they worked was not large (about 20,000 inhabitants), therefore they could not afford to lose any important person. So they met with them personally prior to the invitation of people at first meeting of the working group. They believed that a personal meeting cannot be replaced by any other means of contact. The face-to-face meetings allowed them to introduce themselves and speak clearly about current projects and the efforts to explain the project objectives, expectations, and their potential roles as well as explore how the joint effort might be intensified by the future cooperation. In addition, it could be better explained orally what kind of experts and persons would project need to have in the working group 5 . The members of the project team were aware, from the previous experience, that first meeting was always critically important for further cooperation. Therefore, they paid attention to such aspects as: place, time, form of invitation, program, meeting reminder few days in advance, provide light lunch and snack, an appropriate presentation of the project, etc. They asked the representative of the town hall to provide them with a meeting room on their premises in order to choose a place that would be available easily for each of the stakeholders and would ensure sufficient respect and dignity of the working group. Ensuring the meeting room of the town hall was important for the implementation of the project and thus to demonstrate support of the project by the local municipality. Most of the project team meetings were held in ordinary meeting room of the municipality. One meeting was even in more prestigious meeting room of the Mayor. In addition, the settlement of the local television is in the same building, so it was easier to gain publicity activities for the project.

The cooperation with the officials of the participating institutions has been formally secured by signing of the Memorandum. The Memorandum of cooperation was signed with each institution only after the first meeting in order the stakeholders will have more time to consider their other commitments. Except for one, all institutions remained until the end. It turned out to be wise achievement by paying particular attention to the details of the Memorandum because it was possible to refer to the project in the course of its realization. The Memorandum contained specific roles for the particular stakeholders unless they were foreseeable at that time, such as providing a meeting room, allowing at least one representative of the institution to participate in the working group meetings, allowing the representative of the organization to travel to the international negotiations of the project, etc. These roles have been included in the text of the Memorandum, nothing that any other form of cooperation will be agreed subsequently in time by both sides additionally. Memorandum was possible to be updated later when further specific measures were clearly stated. Nevertheless, we are inclined to opinion that if the

\footnotetext{
5 Therefore, the term "group of experts" was used initially. Mostly managers of the offices and institutions were commissioned to the working group. The term "stakeholders" was later introduced in English and expresses this category of persons more accurately.
} 
cooperation works well, this formalization is not always necessary. The main objective of cooperation in the framework of a permanent working group was to develop local strategy to promote family literacy of the local Roma community. The strategy began to form on the fourth meeting at which the project team has prepared all available resources such as outcomes and recommendations of the project, a framework for strategy development and so on. We worked in smaller groups for better effectivity and then the results were shared across the entire working group.

The project team did not know what to expect from this type of work at the beginning and to avoid disappointment; we were also satisfied with less ambitious expectations. We were aware that we, as a non-governmental organization, which initiated the project, had no power to require any commitments of the stakeholders. We felt that we had to respect the experience of our key players, to be honest and open in expressing our expectations and commitment to achieve our objective. Recognition and celebration of everyone, even the smallest success, gave us the impetus to move forward and to do a good job at meetings or via e-mail communication. We shared with each other and recognized each step that was made for the project support by any interested party.

The influential individuals can be very useful. We were successful in acquiring the most active stakeholders as we approached closer to the leaders of institutions who usually authorize other competent persons to represent their institution. We also tried to use the right meeting place - conference room at the local authorities served for this purpose very well. I agree that all stakeholders' groups should be represented equally in the dialogue in order to remain credible to the other stakeholders and the wider public. We insisted on the fact that each stakeholder has the space and opportunity to express their thoughts at meetings and make their opinions and recommendations contained in the record. After the meeting, the minutes were sent via e-mail, so that everyone can either approve what has been recorded, or to ask the interested stakeholder to supplement the explanations where necessary.

We have learned in our work that the size of the common good may be for representatives of stakeholders particularly interesting, especially if they work in the social field. As they expressed themselves, they joined the working team because of the objectives and problems that this project is facing. Solutions through family literacy are a relatively new concept, even if they saw some swallows in this area, too. Stakeholders also appreciated having the opportunity to meet with representatives of other institutions with similar objectives with whom they can share their experiences. At the end of the project, they expressed their desire not to waste a joint effort, which have lasted nearly two years, but they wished to have a good and feasible common strategy that would continue in started work and which would have the potential to engage and be beneficial to the whole local community, Roma and non-Roma, too.

\section{Conclusion}

The Europe 2020 is the strategic vision of Europe for the $21^{\text {st }}$ Century. It explains how the EU can turn to smart, sustainable and socially inclusive economy delivering high level 
of employment, productivity and social cohesion. Cohesion policy is operating there, where people live. It plays a key role in achieving the strategic objectives for the year 2020, while ensuring that those at risk of exclusion from the society will not remain on the periphery (www.europskaunia.sk).

Policy proposals directed at improving the integration of Roma into the mainstream society have a fundamental flaw. They are based on the assumption that there are some specific problems of Roma to be addressed. The work with Roma children and their families can be successful only if the wider local community is involved in it - parents, counselling centres, social workers, institutions and organizations dealing with family problems in the social exclusion, activation staff of the community and so on. The community is environment or group of people who are regardless of the differences, able to appreciate differences, allowing them openly and effectively communicate and work together to achieve common objective. The word community is often used as a synonym for the congregation. The word community comes from the Latin word root common with communicare, communication - communicate.

The community phenomenon of community allows creating and experiencing nonhierarchical, very deep interpersonal bonds, difficult to implement in the current social environment. It allows people to accept, transcend and celebrate their differences and divergences that enable them to communicate effectively, openly and to cooperate by achieving objectives that have been set for the common good. As a consequence, many members of the group, generating a sense of community, experience the feeling of their uniqueness and profound common unity that is rarely or never felt in other groups.

\section{References}

About the Project. [online]. Accessed 7 November 2016. http://www.lit3-project.eu/ about-the-project/.

Act No. 245/2008 Coll. on education; changes and amendments to certain laws. [online]. http://www.minedu.sk/data/USERDATA/Legislativa/Zakony/2008_245.pdf.

Carpentieri, J.D., Litster, J., \& Mallows, D. (2015). Literacy Cubed Need Analysis Report. Brussel: European Commission.

Kaleja, M. (2011). Romové a škola versus rodiče a žáci. [Roma and School Versus Parents and Pupils]. Ostrava: Faculty of Education, Ostrava University in Ostrava.

Kaleja, M. (2014). Determinanty edukace sociálně vyloučených žáků z pohledu speciální pedagogiky. [Education Determinants of Socially Excluded Pupils of Primary Schools from the Perspective of Special Education]. Ostrava: Faculty of Education, Ostrava University in Ostrava. 
Kaleja, M. (2013). Determinanty hodnotových konstruktů ve vzdělávání romských žáků základních škol. [Determinants of the Valued Constructs in Education of Roma Pupils in Primary Schools]. Ostrava: Faculty of Education, Ostrava University in Ostrava.

Kaleja, M. (2015). (Ne)připravený pedagog a žák z prostředí sociální exkluze. [Unprepared Teacher and Pupil from the Social Exclusion Environment]. Opava: Centre for Empirical Research, Faculty of Public Policies, Silesian University in Opava.

Kolaříková, M. (2015). Dítě předškolního věku v prostředí sociální exkluze. [Preschool Child in Socially Excluded Environment]. Opava: Silesian University in Opava.

Kovacs M. et al. (2015). The Shareholders Involving in the Development and Implementation of Effective Policy of Family Literacy. Dolný Kubín: Vrábel' Printer.

Literacy Cubed - Focus on Roma Families project. [online]. http://discovery.ucl. ac.uk/1475761/.

Padak, N., \& Rasinski, T. (2013). Family Literacy Programs: Who Benefits? Ohio: Literacy Resource Center Kent State University.

Petrasová, A., \& Porubský, Š. (2013). The Educational Paths of Roma Pupils from Socially Disadvantaged Backgrounds. Bratislava: OSF.

Petrasová, A. (2011). The content and Process of Education. In Rafael V. (Ed.), Answers to Questions on (de)Segregation of Roma Students in Slovak Education System (pp. 105-118). Bratislava: Open Society Foundation.

PISA SK 2003, 2006, 2009, 2012 and 2015 National Report, Bratislava: ŠPú.

The Europe 2020 Strategy. [online]. Accessed 15 November 2016. http://www. europskaunia.sk/strategia-europa-2020.

Zezulková, E. (2015). Vybrané faktory komunikační kompetence žáků v primárním vzdělávání. [Selected Factors of Communication Competence of Pupils in Primary Education]. Opava: Silesian University in Opava.

\section{Author}

doc. PaedDr. Alica Petrasová, PhD.

Faculty of Education, University of Prešov in Prešov

Department of Special Education

ul. 17 novembra 15, 08016 Prešov, Slovak Republic

alica.petrasova@unipo.sk 